\title{
A Malmquist Index for the Greek Insurance Industry*
}

\author{
Milton Nektarios ${ }^{\mathrm{a}}$ and Carlos Pestana Barros ${ }^{\mathrm{b}}$ \\ ${ }^{a}$ Department of Statistics and Insurance, University of Piraeus, 80 Karaoli \& Demitriou street, Piraeus \\ 18534, Greece. \\ E-mail: nektar@unipi.gr \\ ${ }^{\mathrm{b}}$ Instituto Superior de Economia e Gestão, UECE (Research Unit on Complexity and Economics), \\ Technical University of Lisbon, Portugal. \\ E-mail: Cbarros@iseg.utl.pt
}

The objective of this paper is to estimate the effects of deregulation after the implementation of the Third Insurance Directive in the Greek insurance market. Efficiency and productivity measures are estimated by means of data envelopment analysis, applied to a sample of almost all Greek insurance companies, for the period 1994-2003. The companies are separated into three groups: life, non-life and mixed insurance companies, and a Malmquist Index is estimated for each group. The Malmquist index is decomposed into technical efficiency change (pure technical and scale efficiency) and technological change. It is found that the life sector experienced an average annual productivity growth of 16.1 per cent, the non-life sector had a rate of 6.5 per cent and the group of mixed insurance companies had the lowest productivity of 3.3 per cent.

The Geneva Papers (2010) 35, 309-324. doi:10.1057/gpp.2010.2

Keywords: insurance; Greece; productivity change; Malmquist Index

\section{Introduction}

The Greek insurance market had always been a small and protected market. A major event took place in 1994 with the implementation of the Third Insurance Directive, which intended to deregulate the European Union (EU) insurance markets. A principal objective of deregulation is to improve market efficiency and enhance consumer choice through increased competition. Efficiency gains may occur as a result of market consolidation that has accompanied deregulation. Research evidence on the efficiency effects of deregulation and consolidation has been mixed with some studies showing efficiency gains and others showing efficiency losses.

The objective of this paper is to provide additional information on the effects of deregulation and consolidation by analysing the Greek insurance market. As a result of the implementation of the Third Directive, the number of insurance companies in Greece has declined by 38 per cent between 1994 and 2003 and the average firm size has increased by almost 500 per cent. The observed absence of any substantial supervision of insurance operations has postponed the further consolidation of the

\footnotetext{
* UECE (Research Unit on Complexity and Economics) is financially supported by FCT (Fundação para a Ciência e a Tecnologia), Portugal. This article is part of the Multi-annual Funding Project (POCI/U0436/2006). The authors thank two anonymous referees for their valuable comments and advice.
} 
310

Greek insurance market. In this framework the logical hypothesis is that Greek insurance companies have reacted to the forces of deregulation by attempting to increase productivity and efficiency.

The choice of the Greek insurance market is based on the fact that Greece is the most developed economy in the Balkans and plays a crucial role for any kind of trade in that region. Its strategic location sets the ground for the country to become a leading regional player, especially after the recent expansion of the EU in Eastern and Central Europe. Other studies have focused on the Greek insurance market because of its regional importance. ${ }^{1}$

Another issue is the contribution of the paper to the current literature. Existing research on insurance productivity has concentrated on the U.S. market, with fewer papers examining European markets. There is not, so far, any comprehensive study that examines issues of productivity and efficiency in the Greek insurance market. Such an analysis will identify the main drivers of efficiency and productivity in the aftermath of the implementation of the Third Directive. The results of this study will allow comparisons of the deregulation effects of the Third Directive across the Greek and other European insurance markets.

This paper analyses the Greek insurance market over the ten-year period of 1994-2003, which spans the implementation of the Third Directive. To measure efficiency, we estimate "best practice" frontiers for each year of the sample period, using data envelopment analysis (DEA). Moreover, we evaluate total productivity with the Malmquist Index, an extension of the DEA methodology. Insurance companies are classified into three groups: life companies, non-life companies and mixed companies. Productivity indicators are estimated for all companies in each group.

The paper is organised as follows: in the next section, we describe the contextual setting; the section after that surveys the existing literature on the topic; the subsequent section explains the theoretical framework and presents the data; the penultimate section presents the results for the three insurance sectors; and the final section discusses the results and presents the concluding remarks.

\section{Overview of the Greek insurance market}

The development of the Greek insurance market followed, in general terms, the evolution of the Greek economy and, more specifically, the growth of the financial sector. ${ }^{1}$ There are three distinctive periods in the evolution of the insurance market. First, the period up to the early 1980s, when the insurance market was subject to considerable government intervention and external limitations. The latter were mainly in the form of administrative regulations, imperfect competition, low insurance know-how and inefficient resource allocation. The second period, up to the early 1990s, witnessed the first efforts to modernise the insurance industry. The most important pieces of legislation were Presidential Decree 115/1985 (for the harmonisation of the Greek insurance legislation to the First Insurance Directive) and

\footnotetext{
${ }^{1}$ Kalotychou and Staikouras (2007).
} 
Table 1 Basic characteristics of the Greek insurance market

\begin{tabular}{|c|c|c|}
\hline Characteristic of the insurance market & 1994 & 2003 \\
\hline Number of insurance companies & 161 & 100 \\
\hline Employment & 10.000 & 9.500 \\
\hline Total premium & $€ 1.050$ million & $€ 3.235$ million \\
\hline Life & $€ 506$ million & $€ 1435$ million \\
\hline Non-Life & $€ 544$ million & $€ 1800$ million \\
\hline Average size of firm & $1050 / 161=6.5$ & $3235 / 100=32.3$ \\
\hline $\operatorname{Mix}($ life/non-life) & $48 / 52$ & $44 / 56$ \\
\hline \multicolumn{3}{|l|}{ Market concentration } \\
\hline \multicolumn{3}{|l|}{ 1. Life: } \\
\hline Big 5 & $68.7 \%(E U-15: 45 \%)$ & $62.5 \%(\mathrm{EU}-15: 54 \%)$ \\
\hline Big 10 & $82.9 \%(E U-15: 63 \%)$ & $88.9 \%(E U-15: 75 \%)$ \\
\hline Big 15 & $90.6 \%(E U-15: 72 \%)$ & $97.2 \%(E U-15: 84 \%)$ \\
\hline \multicolumn{3}{|l|}{ 2. Non-Life: } \\
\hline Big 5 & $39.3 \%(E U-15: 32 \%)$ & $42.8 \%(\mathrm{EU}-15: 46 \%)$ \\
\hline Big 10 & $50.9 \%($ EU-15: 48\%) & $58.4 \%($ EU-15: $62 \%)$ \\
\hline Big 15 & $59.1 \%(E U-15: 59 \%)$ & $70.8 \%(E U-15: 71 \%)$ \\
\hline Total premium/GDP & $1.5 \%(\mathrm{EU}-15: 5.9 \%)$ & $2.1 \%($ EU-15: $7.7 \%)$ \\
\hline Life premium/GDP & $0.7 \%(\mathrm{EU}-15: 2.6 \%)$ & $0.9 \%$ (EU-15: 4.4\%) \\
\hline Non-life premium/GDP & $0.8 \%(\mathrm{EU}-15: 3.2 \%)$ & $1.2 \%($ EU-15: 3.3\%) \\
\hline Investments/GDP & 1.8\% (EU-15: 24\%) & $4.5 \%(\mathrm{EU}-15: 44 \%)$ \\
\hline
\end{tabular}

Source: CEA (2005).

Law 1569/1985 (regarding insurance intermediaries). At the same time, there was a continuous effort to align the practices of local insurance companies with those of their European counterparts. After 1994, the landscape of the Greek insurance market changed definitely, with the internalisation of the Third Insurance Directive. All administrative controls were abolished and pricing was completely liberalised, even in the major fields of Fire and Motor Branches (which had operated on uniform tariffs for many decades).

The introduction of the Greek insurance market into the EU provided an incentive as well as a challenge to the insurance sector for further development and expansion. So far, these goals have not been attained and, furthermore, the expansion in the Balkans and Eastern Europe has been anaemic.

The Greek insurance market is the least developed in the group of EU-15 countries. For this group of insurance markets, the relative share of the Greek market has increased from 0.3 per cent in 1994 to 0.4 per cent in 2003, in terms of total premiums. In Table 1 we observe that the volume of total premiums in the Greek market has increased from $€ 1,050$ million to $€ 3,235$ million between 1994 and 2003. In the same period, the inflation-adjusted average annual growth rate was 6.8 per cent, while in EU-15 it was 4.8 per cent. For the life sector, the inflation-adjusted average annual growth rate was 6.0 per cent (EU-15: 7.3 per cent), whereas for the non-life sector it was 7.5 per cent (EU-15: 2.3 per cent). That is, most of the growth in the volume of business in the Greek insurance market in the period 1994-2003 has come from the faster growth of the non-life sector. This is explained by the fact that Greece has not yet completed the reform of its pensions system. This reform process has contributed 
substantially to the rapid growth of the life insurance sector in most European insurance markets. It is logical, therefore, that the "life/non-life" mix was 48/52 in 1994 (EU-15: 44/56) and 44/56 (EU-15: 57/43) in 2003.

The number of insurance companies has decreased from 161 in 1994 to 100 in 2003, a decrease of about 38 per cent, when the respective decrease in the EU area was 6.5 per cent. Most of the exits of insurance companies were due to insolvencies, while in the same period some major Mergers and Acquisitions (M\&A) projects took place. The reduction in the number of insurance companies has led to the beneficial effect of increasing the average firm size by five times in the period 1994-2003. The number of employees in the insurance sector has decreased from 10.000 in 1994 to about 9.500 in 2003, which represents a decrease of 0.5 per cent on an annual basis (EU-15 decrease: 0.3 per cent).

Table 1 also shows market concentration in the Greek insurance market. Historically, concentration has been very high in the life sector, much higher than the corresponding ratios in the EU-15 area, whereas concentration in the non-life sector is comparable to EU-15 standards.

The relative importance of the Greek insurance market in the domestic economy is below European standards. In Table 1, we may observe that the ratio of total premiums to GDP has increased from 1.5 per cent (EU-15: 5.9 per cent) in 1994 to 2.1 per cent (EU-15: 7.7 per cent) in 2003. The respective ratios for total investments to GDP have been 1.8 per cent (EU-15: 24 per cent) and 4.5 per cent (EU-15: 44 per cent).

\section{Literature survey}

Studies of insurance efficiency employ two basic types of frontier models: the DEA and the stochastic frontier analysis (SFA). Owing to the limited methodological alternatives, most studies are differentiated on the basis of the alternative specifications of inputs and outputs used in these studies. Most of these specifications are based on the "value-added" theory of insurance. ${ }^{2}$

Cummins and $\mathrm{Zi}^{3}$ apply these two methodologies, and also some variants of each, to explore the efficiency of U.S. life insurance companies and conclude that the choice of the efficiency estimation method can make a significant difference. They find that average efficiency is higher for econometric models than for DEA models. Also, efficiency rankings for the Decision Making Units (DMUs) are well preserved in the econometric methods and less preserved between econometric methods and programming methods. Other studies on the U.S. insurance markets include those of Cummins and Weiss, ${ }^{4}$ Gardner and Grace, ${ }^{5}$ and Cummins et al. ${ }^{6}$

In Europe, there was a growth in research about efficiency in the insurance sector during the $1990 \mathrm{~s}$, stimulated by a radical change in the sector, after the

\footnotetext{
${ }^{2}$ Cummins and Weiss (2000).

${ }^{3}$ Cummins and Zi (1998).

${ }^{4}$ Cummins and Weiss (1993).

${ }^{5}$ Gardner and Grace (1993).

${ }^{6}$ Cummins et al. (1999b).
} 
implementation of the single market in European financial services in 1993, which increased competition in Member States and put additional pressure on less-efficient insurers. The studies by Fecher et al. ${ }^{7}$ and Cummins et al. ${ }^{8}$ reflect this environment.

Fecher et al. ${ }^{7}$ use both a parametric approach (a stochastic Cobb-Douglas frontier) and a non-parametric approach (DEA) to construct the efficient frontier. The sample consists on 84 life and 243 non-life French insurance companies. The authors observe that the results are not very sensitive to the approach used, and that there is a great dispersion of efficiency levels between companies. In life insurance, average efficiency is 30 per cent and for non-life it is 50 per cent. Another important conclusion is a positive correlation between the size of the company and efficiency.

Cummins et al. ${ }^{8}$ study the Italian market, considering a sample of 94 companies (life, non-life and mixed) between 1985 and 1993. They use a DEA distance function to estimate the technical efficiency and a Malmquist Index to analyse changes in technical efficiency. Their results show that technical efficiency in the Italian insurance industry ranges from 70 per cent to 78 per cent during the sample period.

Hardwick $^{9}$ analyses the cost inefficiency of the U.K. life insurance companies, using a stochastic frontier approach, between 1989 and 1993. The author concludes that the life insurance industry is very inefficient, namely, that it is possible to produce the same level of output with less than 30 per cent of costs. The author also observes that larger life insurance companies are less inefficient than smaller ones, which he attributes to economies of scale.

Noulas et al. ${ }^{10}$ investigate efficiency of non-life insurance companies in Greece, applying a DEA methodology. The sample includes 12 companies for the period 1991-1996. The results show an average efficiency of 65 per cent, with a great dispersion among companies. The authors conclude that non-life insurance firms are very inefficient, and their survival in the market implies reduction in costs and an improvement in productivity.

Mahlberg and Url ${ }^{11}$ and Ennsfellner et al. ${ }^{12}$ study the Austrian insurance market. These studies use different methodologies to study the impact on efficiency of the single market and of deregulation in the insurance industry. The first study measures the effects of liberalisation on technical efficiency and on productivity between 1992 and 1999, using DEA for the estimation of efficient frontiers, and also construct a Malmquist Index for the transition period. The authors find that the Austrian insurance industry is inefficient, with an average score of about 25 per cent, and that it is possible to reduce costs by increasing the size of the companies. They also observe a reduction in the dispersion of the efficiency scores and in productivity over time, which they explain by an increase in competition. The second study uses a Bayesian stochastic frontier and analyses a similar period, 1994-1999.

\footnotetext{
${ }^{7}$ Fecher et al. (1993).

${ }^{8}$ Cummins et al. (1996).

${ }^{9}$ Hardwick (1997).

${ }^{10}$ Noulas et al. (2001).

${ }^{11}$ Mahlberg and Url (2003).

${ }^{12}$ Ennsfellner et al. (2004).
} 
Their conclusions are consistent with those of Mahlberg and $\mathrm{Url}^{11}{ }^{11}$ showing that efficiency increased in the period, from 61.7 per cent in 1994 to 84.8 per cent in 1999 .

There are two studies on the Spanish insurance industry. Fuentes et al. ${ }^{13}$ analyse the change in productivity in the period 1987-1994, and find that deregulation had little impact on productivity growth. Cummins et al. ${ }^{14}$ study the period between 1989 and 1998 and conclude that industry consolidation was efficiency-enhancing.

Barros et al. ${ }^{15}$ study the efficiency and productivity of the Portuguese insurance market in the period 1995-2001, using a Malmquist index, and find that a large proportion of companies experienced productivity growth, while some experienced a decrease in productivity.

Diacon et al. ${ }^{16}$ provide comparisons among European countries, which is very useful in the context of globalisation. Using Standard \& Poor's Eurothesis database for the years 1996-1999, they analyse technical efficiency of European insurers in different countries, and find striking differences in efficiency. The higher levels of technical efficiency are found in the U.K., Spain, Sweden and Denmark; among the least efficient are the Greek life insurance companies. A previous study on the efficiency and productivity of the insurance industries in the OECD countries is that of Donni and Fecher. ${ }^{17}$

Finally, a recent paper by Fenn et al. ${ }^{18}$ presents an analysis of 14 European insurance markets with a Fourier Stochastic frontier model using Standard \& Poor's EuroThesys database for the years 1995-2001. It is concluded that over the period, most European insurers were operating under conditions of decreasing costs, and that company size and domestic market share were significant factors determining $\mathrm{X}$-inefficiency.

\section{Methodology and data}

In this paper, we adopt the efficient frontier approach, using the Malmquist Productivity Index based on DEA. The Malmquist Productivity Index allows for changes in productivity to be broken down into changes in technical efficiency and changes in technological efficiency.

Formally, the Malmquist Index is based on the output distance function defined as

$$
d^{T}\left(\mathbf{x}^{t}, \mathbf{y}^{t}\right) \equiv \inf \left[\theta:\left(\mathbf{x}^{t}, \frac{1}{\theta} \mathbf{y}^{t}\right) \varepsilon . S^{t}\right]
$$

where $\mathbf{x}$ denotes a vector of inputs, $\mathbf{y}$ is the vector of outputs, $S$ is the technology set and superscript $T$ denotes the technology reference period; usually $T=t$ or $T=t+1$.

\footnotetext{
${ }^{13}$ Fuentes et al. (2001).

${ }^{14}$ Cummins et al. (2004).

15 Barros et al. (2005).

${ }^{16}$ Diacon et al. (2002).

17 Donni and Fecher (1997).

${ }^{18}$ Fenn et al. (2008).
} 
And $1 / \theta$ defines the amount by which outputs in year $t$ could have been increased, given the inputs used, if technology for year $T$ had been fully utilised.

Caves et al. ${ }^{19}$ showed that productivity movements can be measured by a multiinput, multi-output Malmquist Index when input and output data are available in physical units, so that no price index problems arise. They argue that the distance function $d(\mathbf{x}, \mathbf{y})$ can be used in the construction of the Malmquist Index and measure the Malmquist Index of change between $t$ and $t+1$ as the ratio:

$$
d^{T}\left(\mathbf{x}^{t+1}, \mathbf{y}^{t+1}\right) / d^{T}\left(\mathbf{x}^{t}, \mathbf{y}^{t}\right) .
$$

Fare et al. ${ }^{20}$ sought to measure the Malmquist Index as the geometric mean of such indices calculated both for year $t$ and year $t+1$ reference technologies as

$$
\begin{aligned}
M & \left(\mathbf{x}^{t+1}, \mathbf{y}^{t+1}, \mathbf{x}^{t}, \mathbf{y}^{t}\right) \\
& =\left[\frac{d^{t}\left(\mathbf{x}^{t+1}, \mathbf{y}^{t+1}\right)}{d^{t}\left(\mathbf{x}^{t}, \mathbf{y}^{t}\right)} \times \frac{d^{t+1}\left(\mathbf{x}^{t+1}, \mathbf{y}^{t+1}\right)}{d^{t+1}\left(\mathbf{x}^{t}, \mathbf{y}^{t}\right)}\right]^{1 / 2} .
\end{aligned}
$$

Fare et al. ${ }^{20}$ factor this expression into the product of technological change and technical efficiency change as

$$
\begin{aligned}
& M\left(\mathbf{x}^{t+1}, \mathbf{y}^{t+1}, \mathbf{x}^{t}, \mathbf{y}^{t}\right) \\
& \quad=\frac{d^{t+1}\left(\mathbf{x}^{t+1}, \mathbf{y}^{t+1}\right)}{d^{t}\left(\mathbf{x}^{t}, \mathbf{y}^{t}\right)} \times\left[\frac{d^{t}\left(\mathbf{x}^{t+1}, \mathbf{y}^{t+1}\right)}{d^{t+1}\left(\mathbf{x}^{t+1}, \mathbf{y}^{t+1}\right)} \times \frac{d^{t}\left(\mathbf{x}^{t}, \mathbf{y}^{t}\right)}{d^{t+1}\left(\mathbf{x}^{t}, \mathbf{y}^{t}\right)}\right]^{1 / 2} .
\end{aligned}
$$

The ratio outside the brackets is the index of change in technical efficiency (i.e. the change in the distance of the observed production from the current maximum feasible production) between years $t$ and $t+1$, while the bracketed term is the index of change in technology (or technological change) between two periods evaluated at $\mathbf{x}^{t}$ and $\mathbf{x}^{t+1}$.

The Malmquist Index is measured either with the distance function or, alternatively, with the reciprocal of the input distance function $\theta(\mathbf{x}, \mathbf{y})=[1 / d(\mathbf{x}, \mathbf{y})]$. This reciprocal of the input distance function $\theta(\mathbf{x}, \mathbf{y})$ is the smallest ratio by which an input bundle can be multiplied and still be capable of achieving a given level of output. The reciprocal distance function is equivalent to the measure of technical efficiency proposed by Farrell $^{21}$ and is the basis of the efficiency distance ratios used in this analysis. When the Farrell measurement of technical efficiency (the reciprocal of the input or output distance) is used in constructing the Malmquist Index, we obtain productivity growth if $M>1$ and productivity regression if $\mathrm{M}<1$.

\footnotetext{
${ }^{19}$ Caves et al. (1982).

${ }^{20}$ Fare et al. (1994).

${ }^{21}$ Farrell (1957).
} 
316

The Malmquist Index ${ }^{22}$ allows for changes in productivity to be broken down into change in technical efficiency and technological change. Unlike the econometric stochastic frontier approach, it offers a different rate of technological change for each individual unit, which is more appropriate for the purposes of this section, that is the analysis of technological change in the insurance companies. Moreover, since it is estimated with a non-parametric methodology (DEA), it needs neither to impose any functional form on the data, nor to make any distributional assumptions for the inefficiency term.

Additionally, the technical efficiency change can be broken down into pure technical efficiency and scale efficiency. The breakdown of the technical efficiency change into its components is based on the variable returns to scale (VRS) hypothesis. ${ }^{23}$ In Eq. (5) the first term measures pure technical efficiency, the second (bracketed) term measures scale efficiency, while the third (bracketed) term is the index of technological change (the indicator CRS stands for constant returns to scale):

$$
\begin{aligned}
& M\left(\mathbf{x}^{t+1}, \mathbf{y}^{t+1}, \mathbf{x}^{t}, \mathbf{y}^{t}\right) \\
& =\frac{d_{V R S}^{t+1}\left(\mathbf{x}^{t+1}, \mathbf{y}^{t+1}\right)}{d_{V R S}^{t}\left(\mathbf{x}^{t}, \mathbf{y}^{t}\right)} \times\left[\frac{d_{C R S}^{t+1}\left(\mathbf{x}^{t+1}, \mathbf{y}^{t+1}\right)}{d_{V R S}^{t+1}\left(\mathbf{x}^{t+1}, \mathbf{y}^{t+1}\right)} \div \frac{d_{C R S}^{t}\left(\mathbf{x}^{t}, y^{t}\right)}{d_{V R S}^{t}\left(\mathbf{x}^{t}, \mathbf{y}^{t}\right)}\right] . \\
& \times\left[\frac{d_{C R S}^{t}\left(\mathbf{x}^{t+1}, \mathbf{y}^{t+1}\right)}{d_{C R S}^{t+1}\left(\mathbf{x}^{t+1}, \mathbf{y}^{t+1}\right)} \times \frac{d_{C R S}^{t}\left(\mathbf{x}^{t}, \mathbf{y}^{t}\right)}{d_{C R S}^{t+1}\left(\mathbf{x}^{t}, \mathbf{y}^{t}\right)}\right]^{1 / 2}
\end{aligned}
$$

This efficiency measurement assumes that the production function of the fully efficient firm is known. In practice, this is not the case, and the efficient frontier must be estimated from the sample data. Under such conditions, the frontier is relative to the sample considered in the analysis. We developed a Malmquist productivity estimate from mathematical programming models of the frontier production function. For recent surveys, see Fare et al. ${ }^{20}$ Charnes et al., ${ }^{24}$ Coelli et al., ${ }^{25}$ Cooper et al. $^{26}$ and Thanassoulis. ${ }^{27}$ However, Ray and Desli ${ }^{28}$ and $\mathrm{Balk}^{29}$ criticise the Fare et al. ${ }^{20}$ decomposition of the Malmquist Index into pure efficiency change and scale efficiency change based on CRS, proposing the use of VRS.

To estimate the production frontier, we used panel data for the years 1994-2003, obtained from the Association of Insurance Companies of Greece, on 17 life insurance companies, 44 non-life insurance companies and ten mixed insurance companies. Each company is observed for 10 years, allowing to obtain three independent data sets. For

\footnotetext{
${ }^{22}$ Malmquist (1953).

${ }^{23}$ Fare et al. (1990).

${ }^{24}$ Charnes et al. (1995).

${ }^{25}$ Coelli et al. (1998).

${ }^{26}$ Cooper et al. (2000).

27 Thanassoulis (2001).

${ }^{28}$ Ray and Desli (1997).

${ }^{29}$ Balk (2003).
} 
the life insurance companies (10 years $\times 17$ companies) 170 observations, for the non-life insurance companies (10 years $\times 44$ companies) 440 observations and for the mixed companies (10 years $\times 10$ companies) 100 observations. The insurance companies that are considered in this analysis represent almost 90 per cent of the market, thus being adequately representative of the Greek insurance market. We respected the DEA convention that the minimum number of DMUs is greater than three times the number of inputs plus outputs. ${ }^{30}$

Determination of inputs and outputs was based (a) on the alternative specifications of inputs and outputs of the review section above, and (b) on the availability of data. We measured output by (i) invested assets, (ii) losses incurred, (iii) reinsurance reserves and (iv) own reserves; and inputs by (v) labour cost, (vi) non-labour cost and (vii) equity capital. We may note that for life insurance companies the term "losses incurred" is the sum of "life benefits" plus "change in reserves". All variables have been deflated by the GDP deflator $(1994=100)$.

The table with the descriptive statistics of the variables has been omitted, due to the length of the paper.

\section{Empirical results}

The Malmquist Index can be calculated in several ways. ${ }^{19}$ In this study, we estimate an output-oriented Malmquist Productivity Index, based on DEA. Output-oriented efficiency measurements are appropriate if we assume that insurance companies act in a competitive market. ${ }^{31,32}$ In output-oriented models, such as the one adopted in this paper, DEA seeks to identify technical inefficiency as a proportional decrease in input usage.

DEA allows for the estimation of total productivity change in the form of a Malmquist Index. The results of the Malmquist Index, denoting total productivity change, are broken down into technical efficiency change (the diffusion or catch-up component) and technological efficiency change (the innovation or frontier-shift component). Moreover, we break down technical efficiency change into pure efficiency change and scale-efficiency change. The results are presented below and refer to the three groups of insurance companies: life companies, non-life companies and mixed companies.

\section{Life insurance companies}

The Malmquist Indices for the Greek life insurance companies are presented in Table 2. The first column shows technical efficiency, which is broken down to "pure" and "scale" efficiency in columns (3) and (4), respectively. The second column shows technological change, while the last column is the Malmquist Index.

\footnotetext{
${ }^{30}$ Vassiloglou and Giokas (1990).

${ }^{31}$ Khumabhakar (1987).

${ }^{32}$ Zellner et al. (1966).
} 
Table 2 Average technical efficiency change and technological change observed in Greek life insurance companies: 1994-2003

\begin{tabular}{llccccc}
\hline Insurance companies & $\begin{array}{c}\text { MC-Technical } \\
\text { efficiency } \\
\text { change (1) }\end{array}$ & $\begin{array}{c}\text { Technological } \\
\text { change (2) }\end{array}$ & $\begin{array}{c}\text { MC(a)-Pure } \\
\text { technical } \\
\text { efficiency } \\
\text { change (3) }\end{array}$ & $\begin{array}{c}\text { MC(b)-Scale- } \\
\text { efficiency } \\
\text { change (4) }\end{array}$ & $\begin{array}{c}\text { M-Total } \\
\text { productivity } \\
\text { change (5) }\end{array}$ \\
& & & & 1.000 & 1.000 & 1.027 \\
1 & AGROTIKI LIFE & 1.000 & 1.027 & 1.000 & 1.007 & 1.167 \\
2 & AKMI/EFG LIFE & 1.007 & 1.159 & 1.074 & 1.000 & 1.204 \\
3 & ALLIANZ LIFE & 1.074 & 1.121 & 1.000 & 1.000 & 1.104 \\
4 & GENERALI LIFE & 1.000 & 1.104 & 1.179 & 1.007 & 1.285 \\
5 & COMMERCIAL UNION LIFE & 1.188 & 1.082 & 1.075 & 1.011 & 1.488 \\
6 & HELVETIA/POSEIDON LIFE & 1.087 & 1.367 & 1.000 & 0.965 & 1.097 \\
8 & IMPERIO LIFE & 0.965 & 1.137 & 1.000 & 0.997 & 1.180 \\
7 & ELLINOBRETANIKI LIFE & 0.997 & 1.184 & 1.000 & 0.921 & 0.993 \\
9 & INTERAMERICAN INT. LIFE & 0.921 & 1.078 & 1.000 & 0.953 & 1.011 \\
10 & INTERAMERICAN LIFE & 0.953 & 1.060 & 1.153 & 0.986 & 1.197 \\
11 & INTERNATIONAL LIFE & 1.137 & 1.053 & 1.005 & 1.018 \\
12 & INTERSALONICA LIFE & 0.967 & 1.053 & 0.963 & 1.005 \\
13 & METROLIFE LIFE & 1.010 & 1.112 & 1.047 & 0.964 & 1.123 \\
14 & NORDSTERN LIFE & 1.000 & 1.218 & 1.000 & 1.000 & 1.218 \\
15 & OLYMPIAKI/VICTORIA LIFE & 1.074 & 1.092 & 1.066 & 1.008 & 1.173 \\
16 & SCOPLIFE & 1.160 & 1.150 & 1.189 & 0.975 & 1.334 \\
17 & UNIVERSAL LIFE & 1.029 & 1.090 & 1.011 & 1.017 & 1.121 \\
& Mean & 1.033 & 1.122 & 1.044 & 0.989 & 1.161 \\
& Median & 1.007 & 1.104 & 1.000 & 1.000 & 1.167 \\
\hline
\end{tabular}

In Table 2, we can see that the score for total productivity change (the Malmquist Index presented in column (5)) is one or higher than one for almost all insurance companies, with the exception of one, showing that a large proportion of the Greek life insurance companies experienced gains in total productivity in the period considered. The mean score is 1.161 , confirming that for the majority of the insurance companies total productivity increased in the period. Most of the productivity growth is due to technological change and less to technical efficiency.

The change in the technical efficiency score (column (1)) is defined as the diffusion of best-practice technology in the management of the activity and is attributed to investment planning, technical experience, and management and organisation in the insurance companies. For the period under analysis, we can see that it is higher than one for 11 of the insurance companies, out of 17.

The breakdown of the change in technical efficiency into pure technical efficiency change (column (3)) and scale efficiency change (column (4)) shows mixed results, with some insurance companies obtaining simultaneous gains in both areas and others obtaining gains in one but losses in the other. The improvement in pure technical efficiency, which means an improvement in managerial skills, shows that there was investment in organisational factors associated with the management of the insurance companies, such as a better balance between inputs and outputs, best-practice initiatives, more accurate reporting, an improvement in quality 
and so on. The scale efficiency decreases on average in the period. It is important to note that the mean value of pure technical efficiency change is 1.044 and the mean value of scale efficiency change is 0.989 .

Technological change (column (2)) is the consequence of innovation, that is, the adoption of new technologies by best-practice insurance companies. We can see that this index is higher than one for all companies. This indicates that innovation improved in the period for all companies, meaning that there was investment in new technologies (methodologies, procedures and techniques) and in the commensurate skills upgrades related to this.

Overall, we observe two combinations of technical efficiency change and technological change:

(i) In the first group, we find 12 companies, in which improvements in technical efficiency co-exist with improvements in technology change. These are the bestperforming insurance companies in the period.

(ii) In the second group, we find five insurance companies, in which improvements in technological efficiency co-exist with deterioration of technical efficiency. These companies need to upgrade their managerial skills and scale of operation in order to improve their performance.

Hence, our findings include only two combinations of efficiency change out of four possible ones, signifying that there are no companies where improvement in technical efficiency co-exists with deterioration of technological change, neither companies where deterioration in technical efficiency co-exists with deterioration of technological change.

\section{Non-life companies}

The Malmquist Indices for the non-life insurance companies are presented in Table 3.

The first column shows technical efficiency, which is broken down to "pure" and "scale" efficiency in columns (3) and (4), respectively. The second column shows technological change, while the last column is the Malmquist Index.

In Table 3, we can see that the score of the total productivity change (the Malmquist Index presented in column (5)) is one or higher than one for 35 insurance companies out of 44, showing that a large proportion of the insurance companies experienced gains in total productivity in the period considered. The mean score is 1.065 , confirming that for the majority of the non-life insurance companies total productivity increased in this period. Most of the productivity growth is due to technical efficiency and less to technological change (the opposite is true for the life insurance sector).

The change in the technical efficiency score (column (1)) is higher than one for 35 of the non-life Greek insurance companies, with an average value of 1.050 for the period. The breakdown of the change in technical efficiency into pure technical efficiency change (column (3)) and scale efficiency change (column (4)) shows again mixed results. The improvement in pure technical efficiency is higher than one for almost all companies, with an average value of 1.041. The scale efficiency has an average value of only 1.009 .

Technological change (column (2)) is higher than one for all companies with the exception of only 13 companies out of 44 . 
Table 3 Average technical efficiency change and technological change observed in Greek non-life insurance companies: $1994-2003$

\begin{tabular}{|c|c|c|c|c|c|c|}
\hline & Insurance companies & $\begin{array}{l}\text { MC-Technical } \\
\text { efficiency } \\
\text { change (1) }\end{array}$ & $\begin{array}{l}\text { MF- } \\
\text { Technological } \\
\text { change (2) }\end{array}$ & $\begin{array}{l}\text { MC(a)-Pure } \\
\text { technical } \\
\text { efficiency } \\
\text { change (3) }\end{array}$ & $\begin{array}{l}M C(b)-S c a l e- \\
\text { efficiency } \\
\text { change (4) }\end{array}$ & $\begin{array}{c}\text { M-Total } \\
\text { productivity } \\
\text { change (5) }\end{array}$ \\
\hline 1 & AGROTIKI NON-LIFE & 1.016 & 0.995 & 0.909 & 1.118 & 1.011 \\
\hline 2 & AEGAION NON-LIFE & 1.258 & 0.962 & 1.230 & 1.023 & 1.210 \\
\hline 3 & AKMI NON-LIFE & 1.054 & 1.008 & 1.053 & 1.001 & 1.063 \\
\hline 4 & ALLIANZ NON-LIFE & 1.055 & 1.041 & 1.076 & 0.980 & 1.099 \\
\hline 5 & ALPHA NON-LIFE & 1.107 & 0.993 & 1.000 & 1.107 & 1.099 \\
\hline 6 & AMYNA NON-LIFE & 1.062 & 1.017 & 1.056 & 1.005 & 1.080 \\
\hline 7 & ASPIS PRONOIA NON-LIFE & 1.044 & 1.031 & 1.049 & 0.995 & 1.077 \\
\hline 8 & ARGONAYTIKI NON-LIFE & 1.211 & 1.042 & 1.209 & 1.002 & 1.262 \\
\hline 9 & GALAXIAS NON-LIFE & 1.000 & 0.950 & 1.000 & 1.000 & 0.950 \\
\hline 10 & $\begin{array}{l}\text { GENERAL UNION } \\
\text { NON-LIFE }\end{array}$ & 1.036 & 1.012 & 1.033 & 1.003 & 1.049 \\
\hline 11 & $\begin{array}{l}\text { GENIKI EPAGELMATIKI } \\
\text { NON-LIFE }\end{array}$ & 1.080 & 1.009 & 1.058 & 1.021 & 1.090 \\
\hline 12 & GENIKI PISTI NON-LIFE & 1.081 & 1.044 & 1.103 & 0.980 & 1.128 \\
\hline 13 & GENERALI NON-LIFE & 1.121 & 1.040 & 1.080 & 1.037 & 1.165 \\
\hline 14 & DAS NON-LIFE & 0.996 & 1.016 & 1.012 & 0.985 & 1.012 \\
\hline 15 & $\begin{array}{l}\text { DIETHNIS ENOSIS } \\
\text { NON-LIFE }\end{array}$ & 0.996 & 0.995 & 1.000 & 0.996 & 0.991 \\
\hline 16 & DYNAMIS NON-LIFE & 1.050 & 1.025 & 1.046 & 1.004 & 1.076 \\
\hline 17 & EGNATIA NON-LIFE & 1.029 & 1.047 & 0.969 & 1.062 & 1.077 \\
\hline 18 & HELVETIA NON-LIFE & 1.054 & 1.084 & 1.071 & 0.984 & 1.142 \\
\hline 19 & ELLAS NON-LIFE & 0.944 & 0.943 & 0.947 & 0.996 & 0.890 \\
\hline 20 & $\begin{array}{l}\text { ELLINOBRETANIKI } \\
\text { NON-LIFE }\end{array}$ & 0.912 & 1.036 & 0.940 & 0.970 & 0.945 \\
\hline 21 & $\begin{array}{l}\text { EXPRESS SERVICE } \\
\text { NON-LIFE }\end{array}$ & 1.266 & 1.104 & 1.263 & 1.003 & 1.397 \\
\hline 22 & EVROPAIKI PISTI NON-LIFE & 1.029 & 1.012 & 0.945 & 1.089 & 1.041 \\
\hline 23 & $\begin{array}{l}\text { EVROPAIKI PRONOIA } \\
\text { NON-LIFE }\end{array}$ & 1.116 & 1.015 & 1.110 & 1.005 & 1.133 \\
\hline 24 & EVROPI NON-LIFE & 1.179 & 0.980 & 1.181 & 0.998 & 1.156 \\
\hline 25 & EUROSTAR NON-LIFE & 1.112 & 1.006 & 1.101 & 1.010 & 1.118 \\
\hline 26 & IMPERIAL NON-LIFE & 1.077 & 0.987 & 1.068 & 1.008 & 1.063 \\
\hline 27 & $\begin{array}{l}\text { INTERAMERICAN } \\
\text { ASSISTANCE }\end{array}$ & 0.931 & 0.935 & 0.931 & 1.000 & 0.871 \\
\hline 28 & $\begin{array}{l}\text { INTERAMERICAN } \\
\text { NON-LIFE }\end{array}$ & 1.002 & 1.018 & 1.000 & 1.002 & 1.020 \\
\hline 29 & $\begin{array}{l}\text { INTERAMERICAN ROAD } \\
\text { ASSISTANCE } \\
\text { NON-LIFE }\end{array}$ & 0.932 & 0.805 & 0.932 & 1.000 & 0.751 \\
\hline 30 & INTERLIFE NON-LIFE & 1.117 & 1.030 & 1.137 & 0.982 & 1.150 \\
\hline 31 & INTERNATIONAL NON-LIFE & 1.029 & 1.034 & 1.052 & 0.979 & 1.064 \\
\hline 32 & INTERSALONICA NON-LIFE & 1.066 & 0.959 & 1.060 & 1.006 & 1.023 \\
\hline 33 & $\begin{array}{l}\text { MAGDEMBOURGER } \\
\text { NON-LIFE }\end{array}$ & 1.000 & 1.015 & 1.000 & 1.000 & 1.015 \\
\hline 34 & METROLIFE NON-LIFE & 1.086 & 1.032 & 1.086 & 1.001 & 1.121 \\
\hline 35 & NORDSTERN NON-LIFE & 1.000 & 1.008 & 1.000 & 1.000 & 1.008 \\
\hline 36 & OIKONOMIKI NON-LIFE & 0.952 & 1.018 & 0.948 & 1.004 & 0.969 \\
\hline 37 & OLYMPIAKI/VICTORIA & 1.034 & 0.978 & 1.033 & 1.002 & 1.012 \\
\hline
\end{tabular}


Table 3 (continued)

\begin{tabular}{|c|c|c|c|c|c|c|}
\hline & Insurance companies & $\begin{array}{c}\text { MC-Technical } \\
\text { efficiency } \\
\text { change (1) }\end{array}$ & $\begin{array}{c}M F- \\
\text { Technological } \\
\text { change (2) }\end{array}$ & $\begin{array}{c}M C(a) \text {-Pure } \\
\text { technical } \\
\text { efficiency } \\
\text { change (3) }\end{array}$ & $\begin{array}{c}M C(b) \text {-Scale- } \\
\text { efficiency } \\
\text { change (4) }\end{array}$ & $\begin{array}{c}\text { M-Total } \\
\text { productivity } \\
\text { change (5) }\end{array}$ \\
\hline 38 & PERSONAL NON-LIFE & 1.020 & 0.963 & 1.008 & 1.012 & 0.982 \\
\hline 39 & PIGASOS NON-LIFE & 1.012 & 1.042 & 1.000 & 1.012 & 1.054 \\
\hline 40 & POSEIDON NON-LIFE & 1.042 & 1.139 & 0.972 & 1.069 & 1.187 \\
\hline 41 & PROODOS NON-LIFE & 1.000 & 1.236 & 1.000 & 1.000 & 1.236 \\
\hline 42 & SKOURTIS NON-LIFE & 1.139 & 0.982 & 1.137 & 1.002 & 1.118 \\
\hline 43 & SIDERIS NON-LIFE & 0.990 & 0.989 & 1.000 & 0.990 & 0.979 \\
\hline \multirow[t]{4}{*}{44} & YDROGEIOS NON-LIFE & 0.991 & 1.031 & 1.009 & 0.980 & 1.021 \\
\hline & Mean & 1.050 & 1.013 & 1.041 & 1.009 & 1.065 \\
\hline & Median & 1.042 & 1.015 & 1.033 & 1.002 & 1.063 \\
\hline & Std. Dev. & 0.077 & 0.060 & 0.079 & 0.031 & 0.107 \\
\hline
\end{tabular}

Overall, we observe four combinations of technical efficiency change and technological change:

(i) In the first group, we find 25 companies in which improvements in technical efficiency co-exist with improvements in technology change.

(ii) In the second group, we find ten insurance companies in which improvements in technical efficiency co-exist with deteriorations in technology. These are insurance companies with upgraded organisational factors, but without the innovation inherent to investments in new technology, which would provide leverage for the organisational factors. These insurance companies need to acquire new technology and the necessary commensurate skills upgrades in order to improve their performance.

(iii) In the third group, we find four insurance companies, in which improvements in technological efficiency co-exist with deterioration in technical efficiency.

(iv) In the fourth group, in which deteriorating technical efficiency co-exists with deteriorating technology, we find five insurance companies.

Hence, our findings imply that there is room for adjustments in almost half of the non-life insurance companies, in order to achieve best-practice procedures in insurance management.

\section{Mixed insurance companies}

The Malmquist Indices for the mixed insurance companies are presented in Table 4.

The first column shows technical efficiency, which is broken down into "pure" and "scale" efficiency in columns (3) and (4), respectively. The second column shows technological change, while the last column is the Malmquist Index.

In Table 4, we can see that the score of total productivity change (the Malmquist Index presented in column (5)) is one or higher than one for five insurance companies out of ten, with an average value of 1.033, implying minimal gains in total productivity in the period considered. Most of the productivity growth was due to technical efficiency, whereas there was technological regression during that period. 
Table 4 Average technical efficiency change and technological change observed in Greek mixed insurance companies: 1994-2003

\begin{tabular}{|c|c|c|c|c|c|c|}
\hline & Insurance companies & $\begin{array}{c}\text { MC-Technical } \\
\text { efficiency } \\
\text { change (1) }\end{array}$ & $\begin{array}{c}M F- \\
\text { Technological } \\
\text { change (2) }\end{array}$ & $\begin{array}{c}M C(a) \text {-Pure } \\
\text { technical } \\
\text { efficiency } \\
\text { change (3) }\end{array}$ & $\begin{array}{c}M C(b) \text {-Scale- } \\
\text { efficiency } \\
\text { change (4) }\end{array}$ & $\begin{array}{c}\text { M-Total } \\
\text { productivity } \\
\text { change (5) }\end{array}$ \\
\hline 1 & ASPIS PRONOIA MIXED & 1.000 & 0.897 & 1.000 & 1.000 & 0.897 \\
\hline 2 & ATLANTIKI ENOSIS MIXED & 1.189 & 1.063 & 1.176 & 1.012 & 1.264 \\
\hline 3 & GOTAER MIXED & 0.998 & 0.981 & 1.000 & 0.998 & 0.979 \\
\hline 4 & ETHNIKI MIXED & 1.007 & 1.069 & 1.000 & 1.007 & 1.076 \\
\hline 5 & ESTIA MIXED & 1.036 & 0.913 & 0.960 & 1.080 & 0.946 \\
\hline 6 & EVROPAIKI ENOSIS MIXED & 1.000 & 1.090 & 1.000 & 1.000 & 1.090 \\
\hline 8 & ORIZON MIXED & 1.042 & 0.958 & 1.014 & 1.028 & 0.999 \\
\hline 7 & EVROPAIKI PISTI MIXED & 1.107 & 1.040 & 1.082 & 1.023 & 1.152 \\
\hline 9 & SYNETAIRISTIKI MIXED & 0.978 & 0.895 & 1.000 & 0.978 & 0.875 \\
\hline \multirow{4}{*}{10} & PHOENIX MIXED & 1.000 & 1.056 & 1.000 & 1.000 & 1.056 \\
\hline & Mean & 1.035 & 0.996 & 1.023 & 1.012 & 1.033 \\
\hline & Median & 1.003 & 1.010 & 1.000 & 1.003 & 1.027 \\
\hline & Std. Dev & 0.064 & 0.076 & 0.061 & 0.027 & 0.119 \\
\hline
\end{tabular}

\section{Conclusions}

In this paper we analyse total productivity change in a representative sample of Greek insurance companies between 1994 and 2003, a period of intense volatility in the sector due to deregulation and consolidation. The analysis is based on a DEA Malmquist Index model that allows for the incorporation of multiple inputs and outputs in determining relative efficiencies. Certain conclusions are in order.

First, the most productive sector in the Greek insurance market has been the life sector with an average annual productivity growth of 16.1 per cent, followed by the non-life sector with a corresponding rate of 6.5 per cent, whereas the group of mixed insurance companies experienced a growth rate of only 3.3 per cent.

Second, in the life sector most of the growth in productivity has been the result of improvements in technological change (12.2 per cent annually), whereas scale efficiency has exercised a negative influence.

Third, in the non-life sector, improvements in technology have been minimal (1.3 per cent annually), whereas most of the growth has been the result of advances in technical efficiency (5 per cent annually). Again, scale efficiency has not been a contributing factor in productivity.

Fourth, in the sector of Mixed insurance companies, the situation has been even worse. Technological change has been negative, and the minimal productivity gains have come only from improvements in technical efficiency, although in practice consolidation (by means of major mergers) has affected this sector more than the other two.

Fifth, the above estimates should be compared with those of Noulas et al. ${ }^{10}{ }^{1}$ who find high levels of inefficiency in a data set of 11 non-life Greek insurance companies for the period 1991-1996.

How do these results compare with the results of similar approaches that have been applied in other countries? Cummins et al. ${ }^{34}$ find productivity growth of 4.1 per cent

\footnotetext{
${ }^{34}$ Cummins et al. (1999a).
} 
annually in the U.S. life insurance sector, for the period 1991-1994. Cummins et al. ${ }^{6}$ find virtually no growth in the U.S. property-liability insurance industry for the period 1981-1990. Fukuyama ${ }^{35}$ reports productivity gains of about 19 per cent for Japanese life insurers over the period 1988-1993. Cummins et al. ${ }^{8}$ find productivity gains of 19 per cent for the Italian insurance market for the period 1986-1993. Cummins et al. ${ }^{14}$ find that Spanish stock insurers improved productivity by 3 per cent annually over the period 1989-1996. Finally, Barros et al. ${ }^{15}$ estimate an annual productivity growth of 11.3 per cent for the Portuguese insurance industry.

As a final note, we may suggest some issues for further research. An important extension of the study would be to explore the potential improvement in insurance efficiency of the Greek insurance market, if the process of bankassurance is used more extensively in the framework of the convergence of the financial and insurance sectors. $^{2}$ More specifically, it would be of interest to examine the change in efficiency and productivity of the major local insurers, who have employed the bankassurance model in their marketing activities.

\section{References}

Balk, B.M. (2003) 'The residual: On monitoring and benchmarking firms, industries and economies with respect to productivity', Journal of Productivity Analysis 20(1): 5-47.

Barros, C.P., Borges, M.R. and Barroso, N. (2005) 'Evaluating the efficiency and productivity of insurance companies with a Malmquist Index: A case study for Portugal', The Geneva Papers on Risk and Insurance-Issues and Practice 30(2): 244-267.

Caves, D.W., Christensen, L.R. and Diewert, W.E. (1982) 'The economic theory of index numbers and the measurement of input, output and productivity', Econometrica 50(6): 1393-1414.

Charnes, V.A., Cooper, W.W., Lewin, A.Y. and Seiford, L.M. (1995) Data Envelopment Analysis: Theory, Methodology and Applications, Boston: Kluwer.

Coelli, T.J., Rao, P. and Battese, G.E. (1998) An Introduction to Efficiency and Productivity Analysis, Boston: Kluwer.

Comité Européen des Assurances (CEA) (2005) European Insurance in Figures, Brussels: Comité Européen des Assurances.

Cooper, W.W., Seiford, L.M. and Tone, K. (2000) Data Envelopment Analysis, Boston: Kluwer.

Cummins, J.D., Rubio-Misas, M. and Zi, H. (2004) 'The effects of organizational structure on efficiency: Evidence from the Spanish insurance industry', Journal of Banking and Finance 28(12): 3113-3150.

Cummins, J.D., Tennyson, S. and Weiss, M. (1999) 'Consolidation and efficiency in the US life insurance industry', Journal of Banking and Finance 23: 325-357.

Cummins, J.D., Turchetti, G. and Weiss, M.A. (1996) Productivity and technical efficiency in the Italian insurance industry, working paper 96-10, Wharton School, University of Pennsylvania.

Cummins, J.D. and Weiss, M.A. (1993) 'Measuring cost efficiency in the property-liability insurance industry', Journal of Banking and Finance 17(2-3): 463-481.

Cummins, J.D. and Weiss, M.A. (2000) 'Analyzing firm performance in the insurance industry, using frontier efficiency methods', in G. Dionne (ed.) Handbook of Insurance, Boston: Kluwer, Ch. 24.

Cummins, J.D., Weiss, M.A. and Zi, H. (1999) 'Organizational form and efficiency: The coexistence of stock and mutual property-liability insurers', Management Science 45(9): 1254-1269.

Cummins, J.D. and Zi, H. (1998) 'Comparison of frontier efficient methods: An application to the US life insurance industry', Journal of Productivity Analysis 10(2): 131-152.

Diacon, S.R., Starkey, K. and O'Brien, C.O. (2002) 'Size and efficiency in European long-term insurance companies: An international comparison', The Geneva Papers on Risk and Insurance - Issues and Practice 27(3): 444-466.

\footnotetext{
${ }^{35}$ Fukuyama (1997).
} 
Donni, O. and Fecher, F. (1997) 'Efficiency and productivity of the insurance industry in the OECD countries', The Geneva Papers on Risk and Insurance 22(4): 523-535.

Ennsfellner, K.C., Lewis, D. and Anderson, R. (2004) 'Production efficiency in the Austrian insurance industry: A Bayesian examination', Journal of Risk and Insurance 71(1): 135-159.

Fare, R., Grosskopf, S., Yaisarwarng, S., Li, S.K. and Wang, Z. (1990) 'Productivity growth in Illinois electric utilities', Resources and Energy 12(4): 383-398.

Fare, R.S., Grosskopf, S. and Lovell, C.A.K. (1994) Production Frontiers, The Geneva Papers on Risk and Insurance - Issues and Practice. Cambridge, UK: Cambridge University Press.

Farrell, M.J. (1957) 'The measurement of productive efficiency', Journal of the Royal Statistical Society, Series A 120(3): 253-290.

Fecher, F., Kessler, D., Perelman, S. and Pestieu, P. (1993) 'Productive performance of the French industry', Journal of Productivity Analysis 4: 77-93.

Fenn, P., Vencappa, D., Diacon, S., Klumpes, P. and O'Brien, C. (2008) 'Market structure and the efficiency of European insurance companies: A stochastic frontier analysis', Journal of Banking and Finance 32(1): 86-100.

Fuentes, H., Grifell-Tatje, E. and Perelman, S. (2001) 'A parametric distance function approach for Malmquist Productivity Index estimation', Journal of Productivity Analysis 15(2): 79-94.

Fukuyama, H. (1997) 'Investigating productive efficiency and productive changes of Japanese life insurance companies', Pacific-Basin Finance Journal 5(4): 481-509.

Gardner, L.A. and Grace, M.F. (1993) 'X-efficiency in the US life insurance industry', Journal of Banking and Finance 17(2-3): 497-410.

Hardwick, P. (1997) 'Measuring cost efficiency in the UK life insurance industry', Applied Financial Economics 7(1): 37-44.

Kalotychou, E. and Staikouras, S. (2007) 'De facto versus de jure bank-insurance ventures in the Greek market', The Geneva Papers on Risk and Insurance - Issues and Practice 32(2): 246-263.

Khumbhakar, S.C. (1987) 'Production frontiers - Issues and Practice and panel data: An application to US class 1 railroads', Journal of Business and Economic Statistics 5(2): 249-255.

Mahlberg, B. and Url, T. (2003) 'The effects of the single market on the Austrian insurance industry', Empirical Economics 28: 813-838.

Malmquist, S. (1953) 'Index numbers and indifference surfaces', Trabajos de Estatistica 4: 209-242.

Noulas, A.G., Hatzigayios, T., Lazaridis, J. and Lyroudi, K. (2001) 'Non-parametric production frontier approach to the study of efficiency of non-life insurance companies in Greece', Journal of Financial Management and Analysis 14(1): 19-26.

Ray, S. and Desli, E. (1997) 'Productivity growth, technical progress and efficiency change in industrialised countries: Comment', American Economic Review 87(5): 1033-1039.

Thanassoulis, E. (2001) Introduction to the Theory and Application of Data Envelopment Analysis: A Foundation Text with Integrated Software, Dordrecht: Kluwer Academic Publishers.

Vassiloglou, M. and Giokas, D. (1990) 'A study of the relative efficiency of banks' branches: An application of data envelopment analysis', The Journal of Operational Research Society 41(7): 591-597.

Zellner, A., Kmenta, J. and Dréze, J. (1966) 'Specification and estimation of Cobb-Douglas functions', Econometrica 34(4): 784-795.

\section{About the Authors}

Milton Nekiarios is Associate Professor of Insurance at the Department of Statistics and Insurance, University of Piracus, Greece. His main research interests are in applied insurance issues, catastrophe risk management, and pension systems. He was CEO of Ethniki Insurance Company (1993-1999) and Governor of Social Insurance Organisation of Greece (1999-2004).

Carlos Pestana Barros is Associate Profcssor Economics at Instituto Superior de Economie Gestáo, Technical University of Lisbon, Portugal. He has published papers in insurance in The Geneva Papers, Risk Management and Insurance Review, and European Journal of Operational Research. 